AMERICAN JOURNAL OF FOOD AND NUTRITION

Print: ISSN 2157-0167, Online: ISSN 2157-1317, doi:10.5251/ajfn.2012.2.2.31.36

(C) 2012, ScienceHuß, http://www.scihub.org/AJFN

\title{
Effect of delayed processing on some physico-chemical properties of cassava starch
}

\author{
${ }^{1}$ Ajala Lola, ${ }^{2}$ Otutu, Olatunde Lawrence and ${ }^{3}$ Bamgbose, Adefunke \\ ${ }^{1}$ Department of Food Science and Technology \\ Rufus Giwa Polytechnic, Owo, Ondo State, Nigeria \\ ${ }^{2}$ Joseph Ayo Babalola University, Ikeji Arakeji, Osun State Nigeria \\ ${ }^{3}$ Mashood Abiola polytechnic, Abeokuta, Ogun State Nigeria
}

\begin{abstract}
Fresh cassava was harvested and stored for six days, starch was extracted from the stored cassava on a daily basis throughout the period of storage. The starch produced was analyzed for physical and chemical qualities to see the effect of delayed processing on the quality of the starch. The result of the analysis shows that Moisture, Ash, fat and fibre contents decreased with increase in the number of days of storage. while the protein and the carbohydrates increased with increase in the days of storage. Swelling power and solubility decreased with increase in the days of storage, percentage amylose also decreased with increase in the days of storage meanwhile gelation property was not affected by storage of cassava tuber. Delayed processing of cassava tubers in starch production will reduce the purity and the functional properties of the starch.
\end{abstract}

Key Words: Cassava, Quality, Delayed processing and Starch

\section{INTRODUCTION}

Cassava (Manihot esculenta crantz) is a major food crop in Nigeria, supplying about $70 \%$ of the daily calorie of over 50 Million people (Oluwole et al, 2004). It has also been estimated that cassava provides food for over 500 Million people in the world (Abu et al, 2006). It is essentially a carbohydrate food with low protein and fat (Ihekoronye and Ngoddy, 1985). Edible part of fresh cassava root contains 32 $35 \%$ carbohydrate, $2-3 \%$ protein, $75-80 \%$ moisture, $0.1 \%$ fat, $1 \%$ fibre and $0.75-2.50 \%$ ash (Ihekoronye and Ngoddy, 1985, Oluwole et al, 2004)

Cassava roots are highly perishable and a lot of postharvest losses occur to this commodity during storage due to high physiological activities and activities of micro organisms that entered bruises received during harvesting as well as the inherent high moisture content of fresh roots which promote both microbial deterioration and unfavourable biochemical changes in the commodity (Wenham, 1995)

A major drawback in cassava utilization is that the root starts to spoil after $48 \mathrm{hr}$ of harvest due to physiological changes and microbial activities. Some investigators reported an even shorter period before the tuber become unusable The production of cassava for human consumption has been estimated to be $65 \%$ of cassava products while $25 \%$ is for industrial use, mostly starch (6\%) or animal feed $(19 \%)$ and $10 \%$ lost as waste (Fish and Trim, 1993)

Starch is a major component of roots, tubers and cereals. It functions as a fuel-storage material in the living animals.

Starch is a morphologically complex polymer substance, consisting of loose amorphous regions that are interspersed with highly regular crystalline regions, resulting from the formation of hydrogen bonds between the starch molecules. Traditionally, cassava starch is produced according to the method used by Aseidu, (1989). Cassava tuber is peeled, washed, grated into slurry and sieved using muslin cloth. The starch slurry is allowed to settle for 6 hours and the supernatant decanted while the sediment is washed and dried in the oven at $40^{\circ} \mathrm{C}$

Reports of Rickard et al (1992) showed that fufu processed from deteriorating cassava roots had lower and less desirable elasticity than fufu prepared from fresh roots. Similarly, 'gari' processed from deteriorating roots had lower and less desirable swelling properties than one produces from fresh roots (Rickard et al, 1992)

There had been earlier studies on the possibilities of extracting starch from dry chips and pellets (Horsfall, et.al, 2008). The starches obtained were of low quality suitable only for limited applications. 
So far, there is no economically feasible technique of storing harvested cassava root for long period at a large scale. Compelled by this fact, starch factories are usually located close to the cultivation site to ensure supply of fresh roots.

This study aimed at finding the effect of delayed processing on the physico-chemical properties of cassava starch.

\section{MATERIALS AND METHODS}

Materials: Fresh cassava tubers harvested from the farm of Rufus Giwa Polytechnic, Owo Ondo State were used for the research. All chemicals used are of the analytical grade and determinations carried out in triplicates.
Preparation of cassava starch: Fresh cassava was harvested and stored for six days, starch was extracted from the stored cassava on a daily basis throughout the period of storage. Cassava starch was produced according to the method of Aseidu 1989. The cassava root was weighed immediately after harvesting from farm into six parts of $10 \mathrm{~kg}$ each. Peeled cassava tuber was washed in water, the washed tuber was grated and the screened starch was allowed to settle and decanted. The production process is represented in Fig. 1. The percentage yield was calculated and the final product packaged in high density polyethylene to prevent moisture and air intake from the atmosphere.

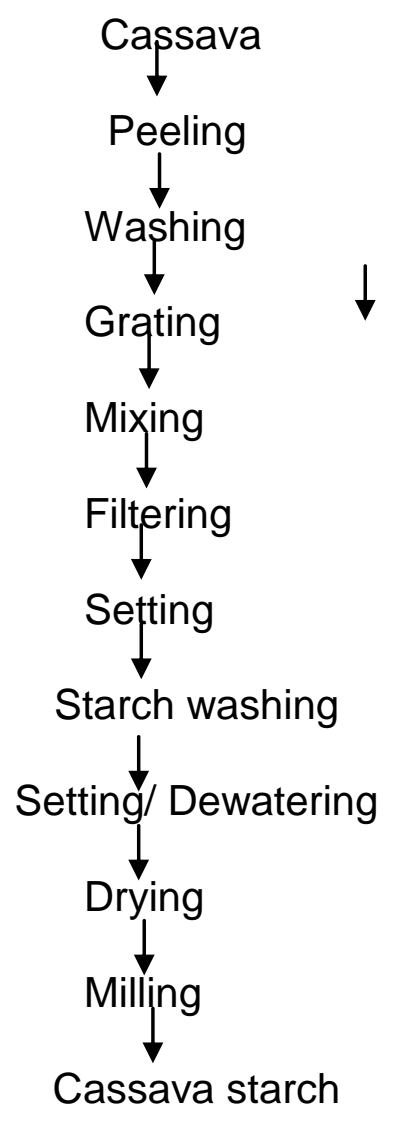

Fig. 1 Flow Chart of Cassava Starch Production (Aseidu 1989). Musilin bag was used to sieve 
Chemical Analysis: The proximate analysis was carried out according to AOAC, (1990).

Starch Determination: Starch was determined according to AOAC, (1990)

Sugar Determination: The sugar content of the sample was determined using AOAC (1990).

Vitamin C Determination: The vitamin C content of the sample was determined by the method of Pearson (1991)

\section{Determination of Functional Properties}

Determination of Water Absorption Capacity: Water absorption capacity was determined using the method of Sathe et al (1982) with slight modifications. $10 \mathrm{ml}$ of distilled water was added to $1.0 \mathrm{~g}$ of each sample in a beaker, the suspension was stirred using magnetic stirrer for 3 minutes and the 1,00rpm the suspension was centrifuged at $3,500 \mathrm{rpm}$ for 3 minutes and supernatant measured in $10 \mathrm{~cm}^{3}$ graduated measuring cylinder. The density of water was assumed to $1 \mathrm{~g} / \mathrm{cm}^{3}$. water absorbed was calculated as the difference between the initial volume of water added to the sample and the volume of the supernatant, water absorbed was calculated from excess weight of the sample.

Weight $(\%) \equiv$ volume of absorbed $\quad x \quad 100$

Determination of Bulk Density (Bd): The procedure of Narayana and Narasinga (1984) was slightly modified and used for all the processed samples. A specified quantity of the sample of each of the differently processed flour was put into an already weighed $5 \mathrm{ml}$ measuring cylinder (W1) it was gently tapped to dominate air spaces between the flour in the measuring cylinder and the volume was noted to be the volume of the sample used. The new mass of the sample and measuring cylinder recorded (W2). Both the volume and mass of the flour sample were determined, the bulk density was computed as:

$$
\mathrm{BD}=\frac{\mathrm{W} 2-\mathrm{W} 1}{\text { Volume of sample }}
$$

Particle Size Determination: The method of Ukpabi and Ndimele (1990) was used. This was done by placing a standard weight of $50 \mathrm{~g}$ each of the sample into the topmost sieve of a six-sieve Endecoff Test. Sieve Shaker (No 6247 aperture 10, 20, 40, 60, 80, $100 \mathrm{~mm}$ ) which was then switched on for 10 minutes after 10minutes the samples retained on each sieve were weighed and recorded and used to calculate the average particle size by plotting a graph of EM/M against 1 . EM/M, the point were the two curve meet denotes the average particle size of the samples.

\section{RESULTS AND DISCUSSION}

The results obtained on the physical analysis of cassava root pulp and starch as presented in Figures $2 \& 3$ shows that the percentage pulp obtained had a high value of $80 \%$ on the $1^{\text {st }}$ day of harvest, for the remaining days decrease in the weight of the pulp was recorded as $78 \%$ on the $2^{\text {nd }}$ day, $74 \%$ on the $3^{\text {rd }}$ day, $72 \%$ on the $4^{\text {th }}$ day, $70 \%$ on the $5^{\text {th }}$ day and $66 \%$ on the $6^{\text {th }}$ day.. This decrease may be due to physiological activities within the cassava tuber and spoilage due to vascular streaking, especially as from day 3 . It was also observed that the weight of the tuber reduced from $10 \mathrm{~kg}, 9.6 \mathrm{~kg}, 9.5 \mathrm{~kg}, 9.5 \mathrm{~kg}, 9.4 \mathrm{~kg}$ and $9.3 \mathrm{~kg}$ for days $1,2,3,4,5$ and 6 respectively. The tuber began to shrink as from the third day as a result of moisture loss.

The $\%$ starch obtained on the $1^{\text {st }}$ day was $8.75 \%$. The yield of the starch decreased as the processing was delayed to $8.33 \%$ for the $2^{\text {nd }}$ day, $8.78 \%$ for the $3^{\text {rd }}$ day, $8.33 \%$ for the fourth day and $8.57 \%$ for the fifth day. By the $6^{\text {th }}$ day \% yield has reduced to $8.3 \%$. This reduction can also be attributed to spoilage due to microbial attack and vascular streaking.

The result of the proximate composition is shown in Table 1. The moisture content ranged between $9.02 \%, 8.07 \%, 8.75 \%, 8.69 \%, 8.56 \%$ and $8.52 \%$ for the corresponding days $1,2,3,4,5$ and 6 . This is indicative of the fact that moisture is loss during storage of tubers. The moisture content is generally low and this is an indication of stable shelf life if properly packaged and stored. Low moisture is necessary in starch for good keeping quality and longer shelf life.

The ash content was $0.25 \%$ on day one, gradual reduction in ash content was noticed to $0.24 \%$, $0.20 \%, 0.17 \%, 0.16 \%$ and $0.12 \%$ on days $1,2,3,4,5$ and 6 respectively. Ash is an indication of the mineral content in the sample; this reduction may be due to degradation of naturally occurring chemicals and loss due to spoilage. 
Table 1: The Proximate Composition of Cassava Starch at Different Days of Storage

\begin{tabular}{|l|l|l|l|l|l|}
\hline Day & Moisture & Ash & Protein & Fat & CHO \\
\hline 1 & $9.02 \pm 0.00$ & $0.25 \pm 0.00$ & $0.43 \pm 0.01$ & $0.30 \pm 0.01$ & $90.53 \pm 0.81$ \\
\hline 2 & $8.07 \pm 0.03$ & $0.24 \pm 0.01$ & $0.56 \pm 0.09$ & $0.26 \pm 0.00$ & $89.98 \pm 0.01$ \\
\hline 3 & $8.75 \pm 0.02$ & $0.20 \pm 0.00$ & $0.67 \pm 0.00$ & $0.21 \pm 0.00$ & $90.17 \pm 0.00$ \\
\hline 4 & $8.69 \pm 0.00$ & $0.17 \pm 0.02$ & $0.72 \pm 0.08$ & $0.17 \pm 0.02$ & $90.25 \pm 0.00$ \\
\hline 5 & $8.56 \pm 0.01$ & $0.16 \pm 0.01$ & $0.76 \pm 0.00$ & $0.14 \pm 0.01$ & $90.39 \pm 0.01$ \\
\hline 6 & $8.52 \pm 0.00$ & $0.12 \pm 0.01$ & $0.89 \pm 0.09$ & $0.12 \pm 0.01$ & $90.36 \pm 0.00$ \\
\hline
\end{tabular}

important parameter especially in characterization of

However the protein content was found to be increasing as the day was progressing from $0.43 \%$, $0.56 \%, 0.67 \%, 0.72 \%$. $0.76 \%$ and $0.89 \%$ for days 1 , $2,3,4,5$ and 6 respectively the source of this protein may likely due to the presence of spoilage organisms that as been processed along with the cassava.

There was reduction in the fat content from $0.30 \%$ in day one to $0.26 \%, 0.21 \%, 0.17 \%, 0.14 \%$ and $0.12 \%$ for days 2, 3, 4, 5 and 6 respectively. This is also attributable to the action of the spoilage agents of cassava which must have fed on the fat for growth.

Nevertheless there is no significant difference in the total carbohydrate content of the cassava from day one when $90.53 \%$ was recorded to day six when we have $90.36 \%$ carbohydrate

The result of the swelling property is presented in table 4, a delay in the processing of cassava tuber has a negative effect on the swelling property. A decrease in the swelling property from $456.20 \%$ in the freshly harvested cassava to $120.63 \%$ on the last day of harvest was observed. Swelling power is an starches from different botanical origins which display different swelling powers at a given temperature (Moorthy, 2002; Charles et al., 2004). It also affects both the eating quality of cassava roots and the use of starch in a number of industrial applications (Moorthy, 2002). High swelling power results into high digestibility and ability to use starch in solution suggesting improved dietary properties and the use of starch in a range of dietary applications.

It has been reported that the amylose acts both as diluents and inhibitor of swelling, especially in the presence of lipids which can form insoluble complexes with some of the amylose during swelling and gelatinization. The starch molecules are held together by hydrogen bonding in the form of crystalline bundles, called micelles. Thus, swelling power and solubility patterns of starches have been used to provide evidence for associative binding force within the granules (Oladebeye et.al 2009) the percentage solubility and the amylose content of the starch decreases as the days of delayed processing increases. Meanwhile delayed processing has no effect on the gelation property.

Table 2: The Result of the Functional Properties of Cassava

\begin{tabular}{|c|l|l|l|l|}
\hline Day & Swelling Power\% & $\begin{array}{l}\text { Solubility } \\
\%\end{array}$ & Gelation \% & Amylose \% \\
\hline 1 & $456.20 \pm 0.75$ & $50.37 \pm 0.00$ & $4.00 \pm 0.00$ & 25.17 \\
\hline 2 & $446.54 \pm 0.00$ & $43.89 \pm 0.01$ & $4.00 \pm 0.00$ & 20.91 \\
\hline 3 & $417.31 \pm 0.00$ & $39.60 \pm 0.00$ & $4.00 \pm 0.00$ & 16.64 \\
\hline 4 & $311.14 \pm 2.74$ & $39.61 \pm 0.00$ & $4.00 \pm 0.00$ & 13.19 \\
\hline 5 & $269.07 \pm 0.01$ & $35.62 \pm 0.00$ & $4.00 \pm 0.00$ & 8.12 \\
\hline 6 & $120.63 \pm 0.01$ & $28.82 \pm 0.01$ & $4.00 \pm 0.00$ & 3.86 \\
\hline
\end{tabular}




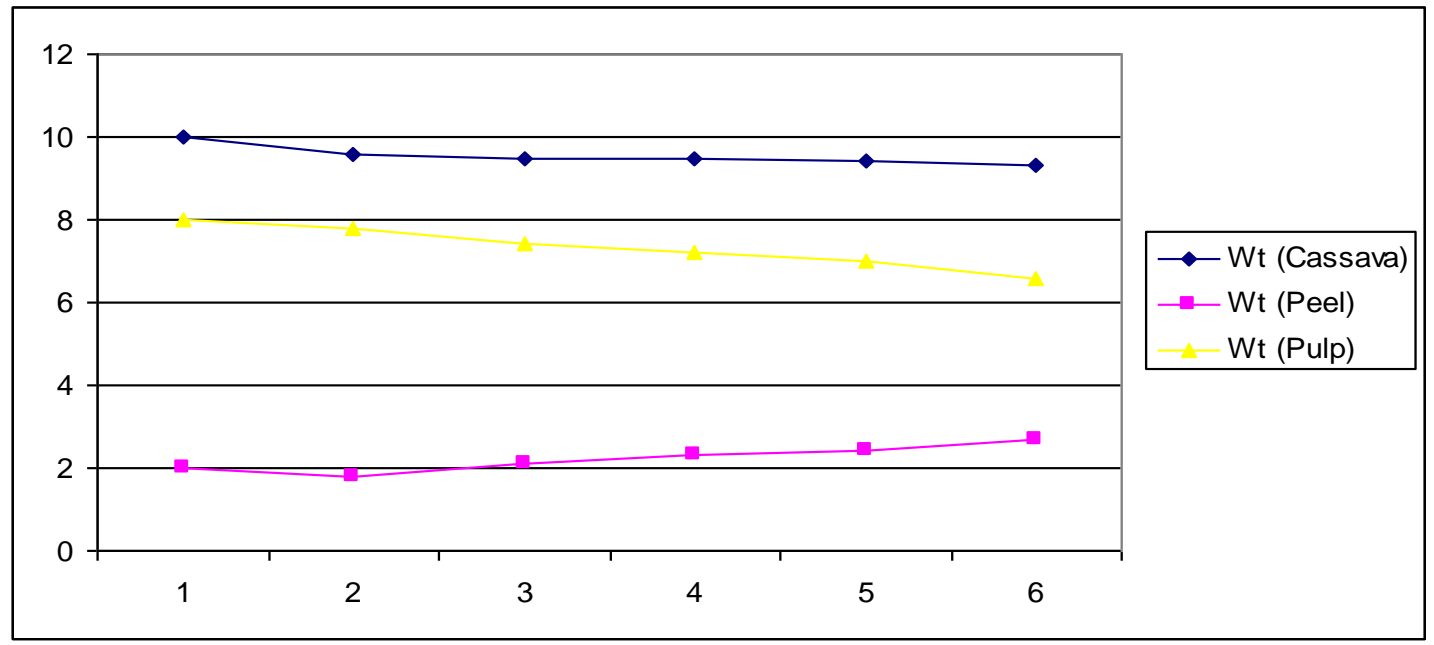

Fig. 2 Effect of Delayed processing on the Weight of Cassava, Peel and Pulp

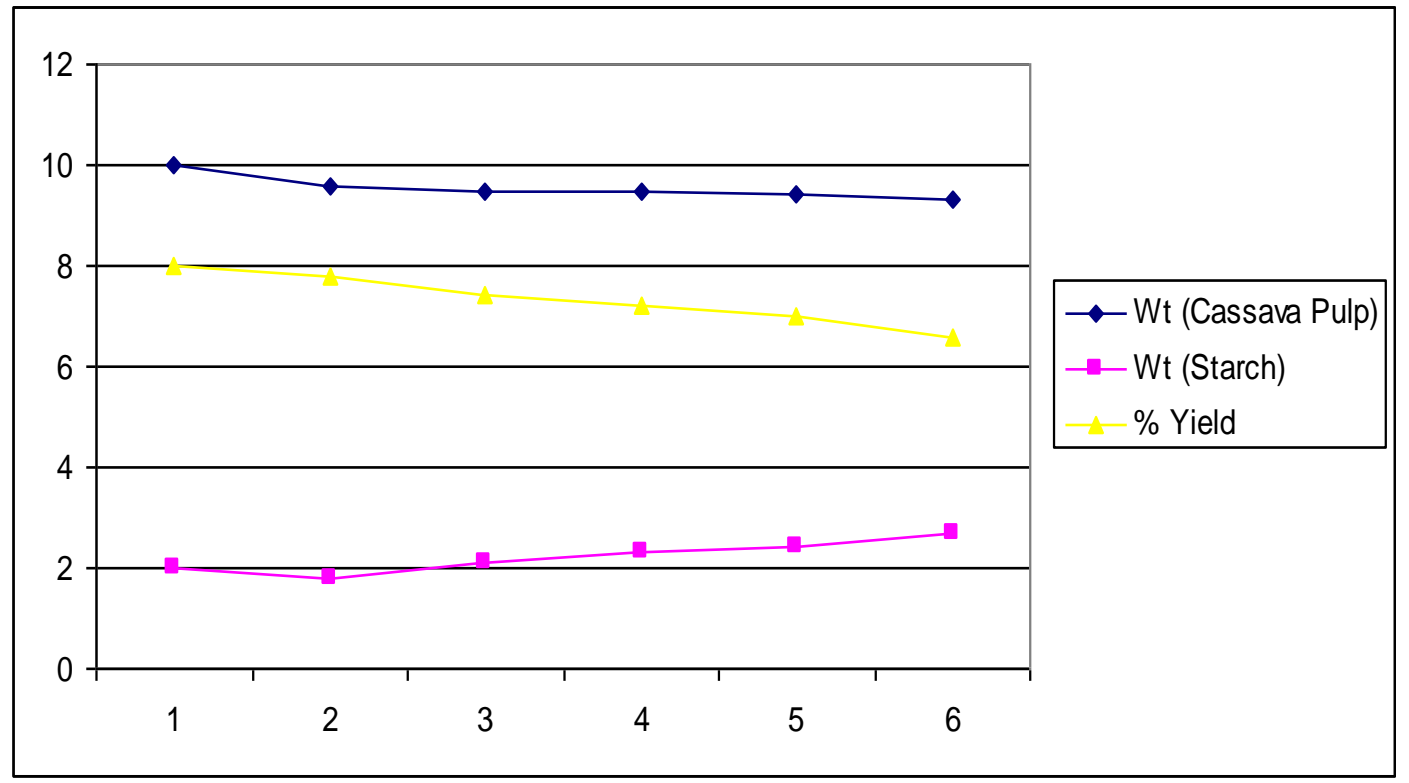

Fig. 3. Effect of Delayed Processing on the percentage yield of Cassava Starch

\section{CONCLUSION}

Cassava root starts to spoil after $48 \mathrm{hr}$ of harvest due to physiological changes and microbial activities. This constitutes a major drawback in its utilization. This present study shows that delay in processing does not affect the percentage carbohydrate content and the gelation property. Starch produced from stored cassava up to 6 days can find usefulness in food processing.

\section{REFERENCES}

A.O.A.C.,(1990). Official Method of Analysis. $14^{\text {th }}$ Ed. Association of Official Analytical Chemist Washington D.C

Abu, J. O. Badifu G. I. O. and Akpapunan, M. A. (2006) Effect of crude palm-oil inclusion on some physicochemical properties of gari, a fermented cassava food product. Journal of Food Science and Technology vol 24 p $73-79$

Aseidu, T.J., (1989), Processing Tropical Crops. Macmillan Edu. Ltd London. Pp 1-22. 
Charles A, Chang Y, Ko W, Sriroth K, Huang T (2004). Some Physical and Chemical Properties of Starch Isolates of Cassava Genotypes. Starch/Stärke 56: 413-418

Fish, D. M. and Trim, D. S. (1993) A review of research in the drying of cassava. Tropical Sci. 33(2): $191-203$

Horsfall, D. M., Eboh, L Aron, A. A. N and Ukpabi J. U . C. (2008) Comparative Evaluation of "Gari" Samples Produced from Fresh Cassava Roots and Dried Cassava Chips. Nigerian Food Journal, Vol 26 No 2. $135-150$

Ihekoronye, A. I Ngoddy, P. O., (1985). Integrated Food Science and Technology for the Tropics. Macmillan Publishers, London.

Moorthy S (2002).Tuber crop starches. Tech Bulletin No. 18 CTCRI, Trivandrum.

Narayana, K and Narasinga-Rao N. S. (1982) Functional properties of raw and processed winged bean (psophocarpus tetragomolbus) flours. Journal of Food Science 47: 1534 -1538

Oladebeye, O.O, Oshodi A.A, Oladebeye A.A, (2009) Physicochemical Properties of Starches of Sweet
Potato (Ipomea batata) and Red Cocoyam(Colocasia esculanta) Cornels. Pakistan Journal of Nutrition 8(4) 313-315 ISSN 1680-51945

Oluwole, O. B.; Olatunji, O. O. and Odunfa, S. A. (2004) A process technology for conversion of dried cassava chips into gari. Journal of Food Science and Technology 22: 65 -77

Pearson, D. (1981), Chemical Analysis of Foods $7^{\text {th }}$ Ed. AVI Publishers West Port.

Rickard, J E. , Masako A. and Blanshard J M V (1991) The physico-chemical properties of cassava starch. International Journal of Tropical Sci. 31, 189 -207

Sathe, S. K.; Salunk, D. K. and Deshande, S. S. (1982) Functional properties of lupin seed protein concentrates. J. Food Sci. 47: 491 - 492

Ukpabi, U. J. and Ndimele, C (1990) Evaluation of the quality of gari produced in Imo state Nigeria. Nigerian Food Journal; 8: 105 - 110

Wenham, J. E (1995) Post-harvest deterioration of cassava. A Biotechnology perspective. F.A.O. plant production and protection paper 130 Rome pp 35. 